\title{
"He was Writing the Book" - Lieutenant Commander James P. Croal: The Royal Canadian Navy's Cold War Arctic Specialist ${ }^{1}$
}

\section{Jason Delaney}

Bon nombre de personnes ont marqué de leur empreinte l'exploration et le développement de l'Arctique canadien. Le présent récit porte sur le Capitaine de corvette James Patrick Croal, spécialiste de l'Arctique de la Marine royale canadienne dont les contributions modestes mais tout de même importantes sont survenues pendant la période déterminante des premières années de la guerre froide. Depuis la fin de la Seconde Guerre mondiale jusqu'à sa retraite en 1965, James Croal a collaboré à faire reculer les obstacles entourant la frontière de l'Arctique canadien à une époque où les connaissances et l'expertise étaient limitées. Dans le cadre de l'intérêt croissant à l'égard de l'Arctique canadien, bien des gens se sont tournés vers Big Jim Croal puisqu'à l'époque, c'était lui l'expert en la matière.

The Arctic is a distinct and often hostile environment where effective operations require special knowledge, equipment and skills. Throughout history, interest in Canada's archipelago has come and gone as surely as the ocean's tides and ice flows, particularly with respect the once elusive Northwest Passage. One particular period was shortly after the Second World War as the Cold War began to evolve. In addition to daring, mystery and a pioneering spirit, ventures into Canada's north during the early post-war period involved hydrographic surveys, ice reporting, oceanography and improving the ability to navigate at high latitudes without a magnetic compass. This interest in Arctic science and exploration, was strongly influenced by the growing American northern presence and an evolving threat from its superpower rival, the Soviet Union. For two and a half decades, Lieutenant Commander James Patrick Croal, was either directly or indirectly involved in many of these activities, eventually becoming known as the Royal Canadian Navy's (RCN) Arctic specialist.

An account of his life's work is of interest for two reasons. First, it is a vehicle for examining the developments in Arctic matters during the formative yeas of the Cold War.

\footnotetext{
${ }^{1}$ This article is based on a paper originally presented at the Centre for Foreign Policy Studies' annual Sea Power/Maritime Security Conference held in Halifax, Nova Scotia, 16-18 June 2010.
}

The Northern Mariner/Le marin du nord, XXV, No. 4 (October 2015), 399-412 


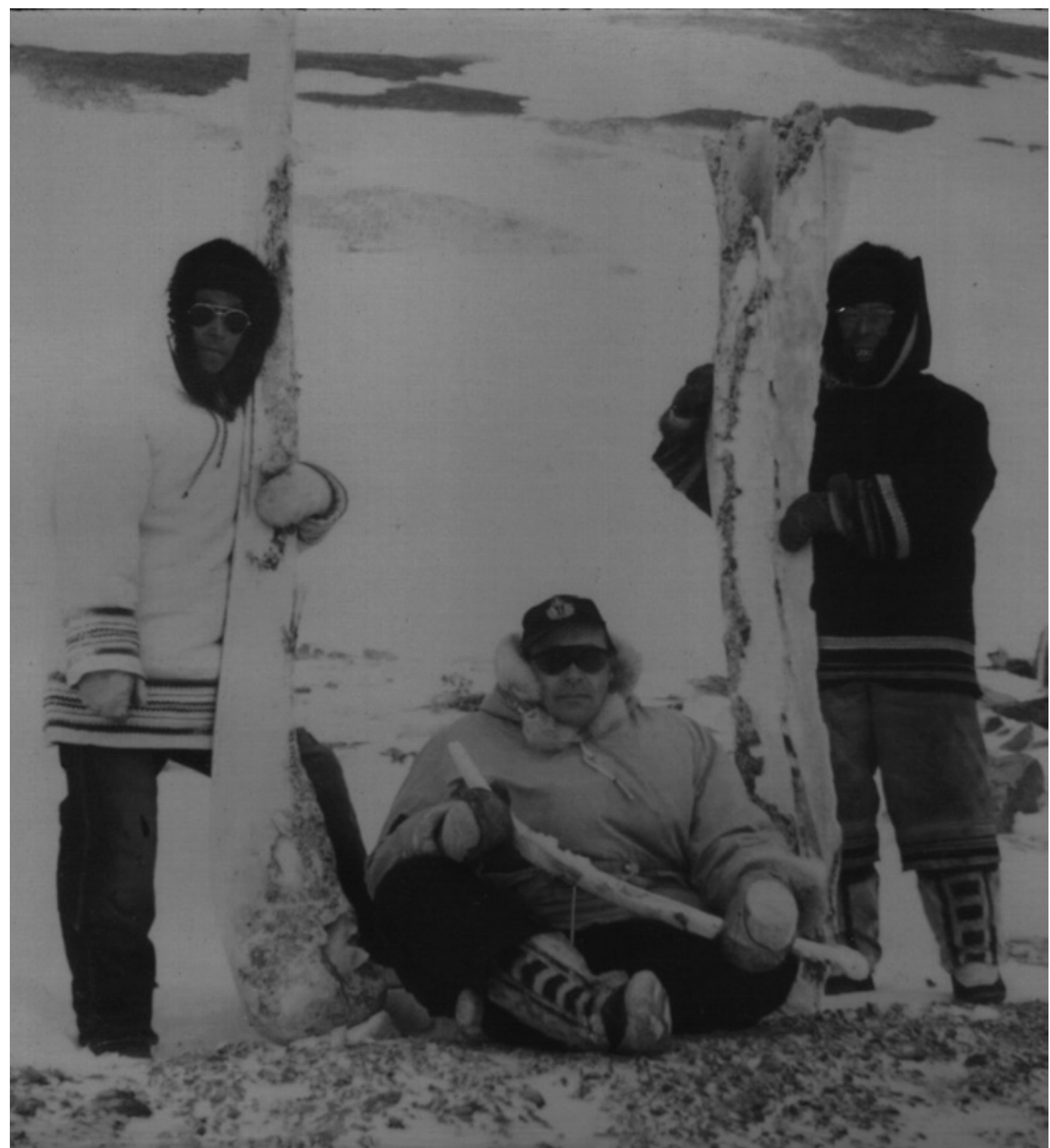

LCdr Croal in the Arctic with two Inuit guides (Croal Family Collection)

Second, it is the life of an extraordinary Canadian who, like many others, has nonetheless been forgotten over time.

James Croal was born in Galt, Ontario in 1916 and after school took a job with the International Nickel Company in Cooper Cliff, Ontario where he worked in open pit mining. He was working as driller and shift boss when war broke out. By September 1943, he enlisted as an ordinary seaman in the Royal Canadian Navy Volunteer Reserve. He was granted a temporary commission as a probationary sublieutenant as of 27 March 1944 and 
sent to the officer training establishment, HMCS Kings in Halifax that summer. After completing the introductory course for executive branch officers in 1945, he was appointed to the River class frigate, HMCS Orkney; however, the war ended before he saw much action.

After the war, as the navy began to demobilize allowing thousands of sailors to return to their regular lives, Croal remained in the navy's interim force. That fall, Naval Service Headquarters sent a message looking for volunteers for a three-month special assignment in the sub-arctic. To say that this was not a desirable position goes without saying, but Croal applied and desperately hoped to be selected. He was chosen and offered a short service appointment as an acting lieutenant with the Naval Secretariat's Directorate of Inter-Service Research and Development. The special assignment was to test cold weather clothing and equipment and be the navy's observer on exercise Musk Ox: a three thousand mile military expedition that started in Churchill, Manitoba and went across the ice above the Arctic Circle to Victoria Island and then south to Edmonton. Musk Ox was one of a series of non-tactical exercises designed to test the military's ability to operate in the harsh environment of Canada's north. ${ }^{2}$ Although Croal's assignment was to test and observe, by the time the expedition reached its final destination, its success was due, in no small part, to "Big Jim" Croal. ${ }^{3}$

The Canadian Army mounted the exercise while the Royal Canadian Air Force supported the exercise by means of air drop resupply. ${ }^{4}$ To mount such an audacious expedition, the army relied upon the experience of a few key individuals. Lieutenant Colonel P.D. Baird led the expedition. He had first gone to the Arctic on Sir James Wordie's 1934 Arctic expedition. He had also been a member of a joint British-Canadian Arctic expedition from 1936-39. At the end of the war he and participated in similar, smaller-scale operations out of Fort Churchill. ${ }^{5}$ Lieutenant Colonel Graham Rowley was in charge of the advance party. He had gained his experience as a young archaeologist on the same 1936-39 BritishCanadian Arctic expedition. The army also enlisted the expertise of the indomitable Lieutenant Colonel Andrew Croft, a British wartime veteran of the Special Operations Executive. Before the war, Croft had gained the reputation as a daring Arctic explorer for his work on Sir Martin Lindsay's British Trans-Greenland expedition of 1934. He also set the world record for the longest self-sustaining journey across the Arctic by dog sled - which he held for sixty years. ${ }^{6}$ Baird also enlisted the help of Tom Manning, a scientist and explorer whom he knew from Churchill and was known for charting portions of Foxe Basin and Baffin Island in the 1930s and 1940s. ${ }^{7}$ These men were some of the veteran Arctic

\footnotetext{
2 See Kevin M. Thrasher, “Exercise Musk Ox: Lost Opportunities," unpublished MA thesis, Carleton University, Ottawa, 1998.

3 Jim Croal was often called "Big Jim" because of his stature at 6'2" and 235lbs.

${ }^{4}$ For an account of the RCAF support to this exercise, see Larry Milberry, Canada's Air Force at War and Peace, vol. III, (Toronto 2001), 302-305.

5 The previous exercise was called "Lemming" and was preceded by two other: "Polar Bear" and "Eskimo." Margaret A. Carroll, "Defence Forces Operations in Hudson Bay," Carlyle Smith Beals and Douglas A. Shenstone, eds., Science, History and Hudson Bay, (Ottawa, 1968), II, 915-916.

${ }^{6}$ Obituary for Colonel Andrew Croft, DSO, OBE, The Guardian, July 1998.

7 Tom Manning was commissioned into the RCNVR and assigned to American forces stationed on South Hampton Island as a local expert for the Crimson Route air field constructed there. See Carroll, "Defence Forces Operations in Hudson Bay."
} 
explorers James Croal would come to know on his first assignment in the winter of 1946. The experience would have a profound influence on the rest of Croal's life.

Prior to setting out, the participants had six weeks of cold weather training both at Camp Shilo and Fort Churchill. Although Croal had neither land warfare nor Arctic training, he was a rugged outdoorsman and was comfortable in the environment, given his pre-war northern Ontario work. He became captivated by the Arctic and was able to live and work with relative ease in the unforgiving climate. This, coupled with his evident enthusiasm, quickly earned him the confidence of Baird and his associates. During the second half of the three-month venture, they assigned Croal the responsibility of forward reconnaissance to scout out obstacles which might impede the expedition's progress. ${ }^{8}$ The plan was to move the force through the northern territories at the height of the spring thaw and flood season to experience the worst possible conditions. ${ }^{9}$ Croal scouted ahead by aircraft and drew up a plan including a route through uncharted territory with recommendations on how to navigate the water obstacles. ${ }^{10}$ He then executed the plan despite the best efforts of the local wildlife.

Naval Lt. Jim Croal and his three helpers had left Norman Wells two weeks earlier, and used a glider to haul in an U.S. Army amphibious Weasel. Along the route, through 100 miles of bush, they had built corduroy roads across the swamps and bridges over the streams and rivers. This operation had been christened "Tadpole", an appropriate name, as the work was largely done under water. The beavers, those busy Canadians, comprised most of the local population. Where they built dams miniature lakes would be formed, blocking the movement of land vehicles. Sometimes they were clever enough to wait until Croal and Company had constructed a bridge, then build a dam downstream to wash out the structure. ${ }^{11}$

Eventually, the force negotiated perilous terrain and swelling rivers, including the Petitot and Nelson Rivers, and made it safely to Edmonton. Much of this success was attributed to Croal and his "tadpoles" who saved time on an exercise that was behind schedule and under considerable media scrutiny. For his efforts and that of his team Croal was praised by senior expedition staff. ${ }^{12}$ In his study of the expedition Kevin Thrasher asserts that, "James Croal's advance team with their amphibious American M-29 Weasel deployment by Hadrian Glider on the southern portion of the route was crucial to the ultimate success of Musk Ox."13

After this first foray into the Arctic, Croal petitioned to join the permanent force citing his new skills and experience as a special qualification. But the RCN was not yet ready to commit to northern research or operations so Croal was demobilized on 16 October 1946. The newly formed Defence Research Board (DRB) then expressed an interest in him, not just for his growing knowledge of the Arctic environment, but because of his pre-war experience

\footnotetext{
${ }^{8}$ Letter from Baird to CO, HMCS Bytown, 19 July 1946. Personnel Records Centre, Ottawa, (PRC), Croal O-16805.

9 Lieutenant Colonel G.W. Rowley, "Exercise MUSKOX," The Geographical Journal, CIX, 4/6, (Apr.-Jun. 1947), 175-184.

10 Report to CO, HMCS Bytown from A/Lt J.P. Croal, 17 July 1946. PRC, Croal O-16805.

${ }^{11}$ John Lauder, "Tracks North: The Story of Exercise Muskox," unpublished manuscript. DHH, 96/52, folder 1,95 .

${ }_{12}$ Thrasher, Exercise Musk Ox, 83-85.

13 Thrasher, 102.
} 
in drilling and open pit-mining in northern Ontario. Doctor Geoffery Hattersley-Smith and Moira Dunbar, two of the nation's most prominent scientists working for DRB's Arctic Section, had been following Croal's activities and offered him an opportunity. ${ }^{14}$

Croal was sent back to Churchill in August 1947 as the first DRB employee at the new Joint Canada-US Arctic Experimental Station. ${ }^{15}$ His main task was to learn as much as he could about the permafrost and was the first to take soil temperature recordings around what would eventually become the Defence Research Northern Laboratory. In the process of his work, Croal developed a coring apparatus for obtaining samples of the upper organic layer of permanently frozen ground. ${ }^{16}$ He was easily accepted by the local population and was one of the pioneers of the growing community. He eventually teamed up with Captain Bill Crumlin of the United States Army Corps of Engineers and continued his permafrost tests in conjunction with the US forces stationed there. ${ }^{17}$

Comfortable with the frontier lifestyle, Jim Croal kept himself busy by building a house for his young family while taking an Arctic instructor qualifying course at the joint military base. In the spring of 1948, he was asked to join a northern cruise above the Arctic Circle as an observer onboard the American attack cargo ship USS Wyandot (AKA 92). Together with two American icebreakers, USS Edisto (AG 89) and USCGC Eastwind (WAGB 279), the ships formed Task Force 80 ordered to head north to land supplies for the construction of various northern facilities including the strategic US air base at Thule, Greenland, as well as the station that would become known as the most northern defence facility located at the top of Ellesmere Island - Alert. ${ }^{18}$ Croal found himself in high demand in these remote locations. In fact, the group of engineers surveying for the construction of the RCAF station at Resolute Bay lacked the equipment and knowledge that Croal possessed so they asked him to stay on and assist with the survey, which he did. ${ }^{19}$ From this experience, he had many close calls with death from either exposure after being stranded by ice flows or a brush with a prowling polar bear that wandered into his hut during the night. ${ }^{20}$

Later that summer, the RCN conducted its first northern cruise into Hudson Strait and Hudson Bay. When they visited Churchill - a first for the RCN - Croal was invited onboard the destroyer HMCS Nootka for drinks and lunch. After this, and perhaps receiving some encouragement from the ship's officers, he again petitioned to join the permanent force.

Things were beginning to change since he first applied for a permanent commission with his Arctic experience. The RCN was testing the waters by conducting its first northern cruise, which had brought HMCS Nootka along with HMCS Haida to Churchill that

\footnotetext{
14 The relationship between Hattersley-Smith, Dunbar and Croal was recounted in an conversation between James Croal's son, Peter, and daughter, Bonnie, to author. All three later worked together on Operation Hazen in 1958.

15 Carroll, "Defence Forces Operations in Hudson Bay," 911.

${ }^{16}$ Croal brought along a Boyles Bros. (BB) x-ray diamond drill, which he used with a modified technique to extract the samples. Croal biographical sketch; Library and Archives Canada, Ottawa, (LAC), MG 31, G 34, vol. 1 , file 1 .

17 Carroll, 912.

18 See Peter Kikkert and P. Whitney Lackenboauer, "Setting an Arctic Course: Task Force 80 and Canadian Control in the Arctic, 1948," The Northern Mariner, XXI, 4, (October 2011).

19 J.P. Croal, "First in the Field," personal memories of the Defence Northern Research Laboratory. Croal family collection. Ottawa.

20 "Matelot in Mukluks," The Crowsnest, II, 5, (March 1950), 10-11.
} 
summer. ${ }^{21}$ In considering the voyage, the Naval Board noted that the Naval Staff had been investigating the possibility since no RCN ships had ever been to Hudson Strait or Hudson's Bay. The Board supported the cruise given the, "present interest in the Canadian Arctic."22

This time he was accepted. In June 1949, he was offered a commission in the RCN as a lieutenant (special branch) and was sent back in his old job of testing clothing and equipment at Churchill. Croal spent the summer working out of the joint military base and travelling by sixteen-foot fibreglass canoe testing various military rations and equipment with an American counterpart. ${ }^{23}$

In October 1949, the Arctic Institute of North America asked for Croal, specifically, to take part in an expedition being mounted to investigate the region around Clyde River on Baffin Island. ${ }^{24}$ The request came from Croal's former commanding officer on Musk Ox, Colonel Baird, who was working for the Institute after he retired from the Canadian Army. Baird felt that there were few people he could rely upon better than James Croal, especially if difficulties were to develop. ${ }^{25}$ But the navy did not approve the request stating that the national interest would be better served with Croal remaining at his current duties. ${ }^{26}$

The Arctic was by now becoming a growing concern for the Canadian government because of an increased US military presence. Witnessing this first hand, Croal tried to advise his superiors in the RCN that familiarization in the Arctic ought to become more of a priority. ${ }^{27}$ In early 1950 however, the Naval Board considered this an extra commitment that could not be met and that the navy in due course would take its proper place in Arctic developments. ${ }^{28}$ The Arctic and Canada's sovereignty over the area had not yet reached the height of national attention. In February 1950, Croal found himself on Station Baker in the Labrador Sea between Greenland and Labrador testing clothing and equipment onboard the navy's weather observation ship, HMCS St. Stephen ${ }^{29}$

Later in 1950, James Croal was promoted to lieutenant commander and as of October 1951, was on staff of the assistant chief of naval staff (works) where he served as the coordinator for naval construction at Fort Churchill because of his previous experience with permafrost while working for DRB. On the side, Big Jim trained Army instructors in the art of Arctic survival. ${ }^{30}$ His knowledge and reputation in various facets of Arctic matters was

\footnotetext{
${ }^{21}$ Dr Isabel Campbell, “A Glimpse of Global Warming. RCN Voyages in Northern Waters in 1948,” paper presented at the Centre for Foreign Policy Studies' annual Sea Power/Maritime Security Conference held in Halifax, Nova Scotia, 16-18 June 2010.

${ }_{22}$ Naval Board min. 214-3, 29 April 1947. DHH, 81/520/1000-100/2, box 27, file 4.

${ }_{23}$ Croal biographical sketch; Report on Exercise FISH, 1949. LAC, MG 31, G 34, vol. 1, file 7.

24 Letter from Baird to CO, HMCS Bytown, 14 October 1949. PRC, Croal O-16805.

25 Ibid.

26 Letter from the Naval Secretary to CO, HMCS Bytown, 27 January 1950. PRC, Croal O-16805.

${ }^{27}$ Memo from Croal to CO, HMCS Bytown, 9 November 1949. LAC, MG 31, G 34, vol. 5, file 101.

${ }^{28}$ Letter from the Naval Secretary to CO, HMCS Bytown, 27 January 1950. PRC, Croal O-16805.

29 "Matelot in Mukluks."

${ }^{30}$ Croal created a manual for the indoctrination and training of sub-Arctic instructors which he drafted in April 1950. LAC, MG 31, G 34, vol. 5, file 104.
} 


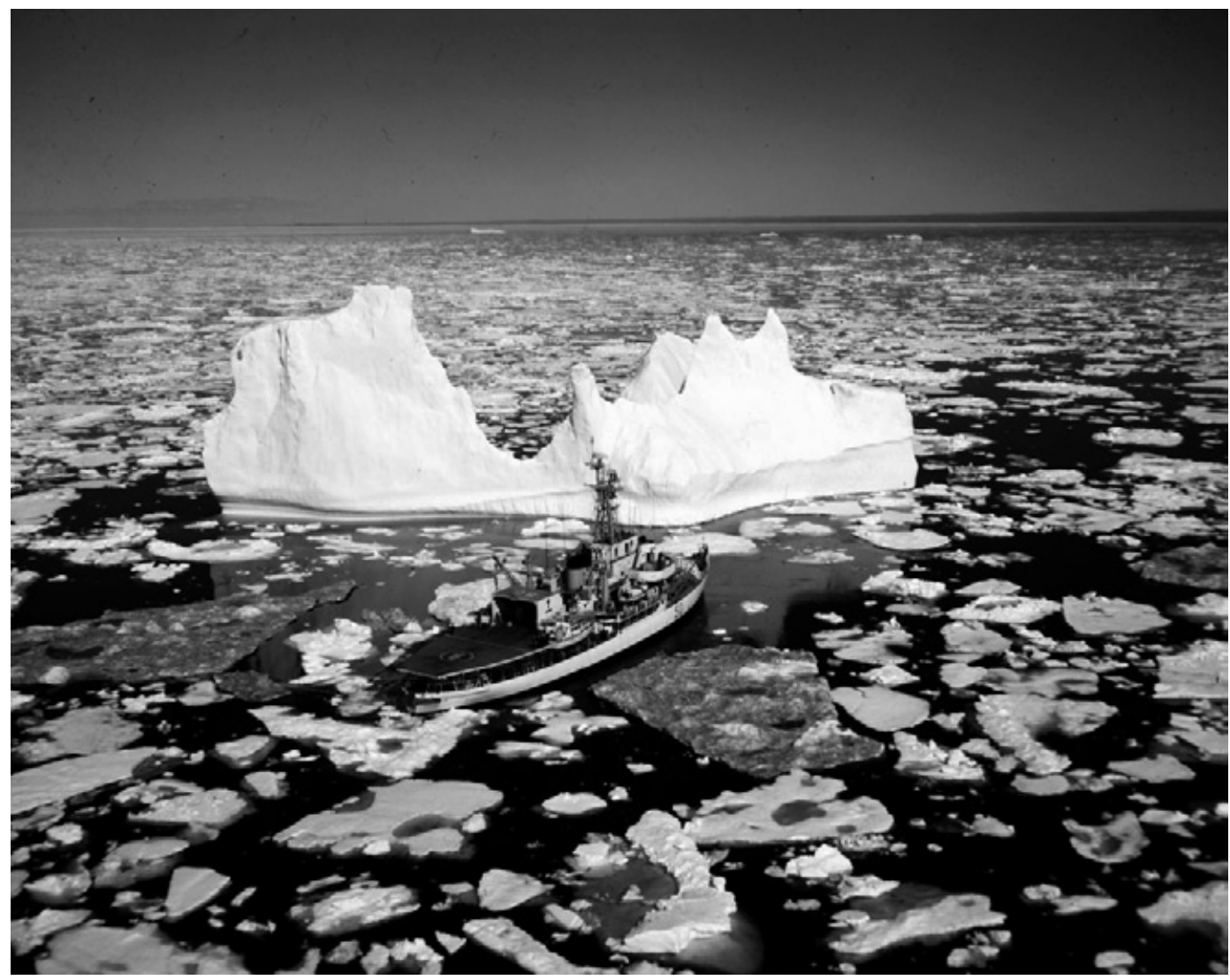

HMCS Labrador alongside iceberg (Library and Archives Canada)

growing and became known to many outside his small circle of Arctic veterans. In April 1952, he was asked to present the naval aspects of Arctic combat at the United Services Institute conference in Montreal. ${ }^{31}$ Then, in August 1953, he was brought to headquarters in Ottawa as the staff officer (Arctic) as the RCN began to prepare for a more concentrated venture into Arctic operations. His work included coordinating the maiden voyage of the navy's new icebreaker, HMCS Labrador, nearing completion at the shipyard in Sorel. ${ }^{32}$

Croal assisted Labrador's commanding officer, Captain O.C.S. Robertson, develop the operational plan for the ship's historic passage into Canada's north. Robertson wanted him in his ship because no one else in the permanent force knew the Arctic better. Many years later, Robertson remarked: "Nowadays there are many people who are experts on Arctic operations... But when he started he was writing the book. ${ }^{" 33}$ However, to serve at sea Croal

31 Various correspondence, c. April 1952. PRC, Croal O-16805.

32 Various correspondence, c. December 1953. PRC, Croal O-16805.

33 Comments from Owen Robertson in Alfred Holden, "Lt.Cmdr. James Croal noted for Arctic Work." Toronto Star. c. 1985 upon the death of J. P. Croal. 
had to transfer back to the executive branch. This done, he was appointed as the gunnery officer $^{34}$ (in a ship that did not have any heavy naval armament). Thus Croal served in Labrador during the ship's 1954 maiden voyage when she became the first deep draft vessel to transit the Northwest Passage and the first vessel of any kind to circumnavigate North America.

Other Arctic developments made Labrador's second summer cruise in 1955 just as significant and perhaps more demanding than the first. The United States and Canada had agreed to construct the Distant Early Warning (DEW) Line - a joint venture to build a line of radar sites above the Arctic Circle to provide advance warning of Soviet bombers coming over the polar region.

The Foundation Company of Canada Ltd had been awarded the contract to construct the sites along the eastern portion of the line and they wanted Croal's expertise. In early 1955, the company's project leader petitioned Captain Robertson for Croal's assistance stating that, "in view of the magnitude of the Arctic problems posed by this project, we are most anxious to obtain the best available advice in the early stages. ${ }^{{ }^{35}}$ Croal understood the complexities of building structures on the permafrost, having been the co-ordinator of naval construction in Fort Churchill. With the navy's permission, he went to Foxe Basin north of Hudson Bay to assist the Foundation Company in conducting beach surveys and establishing sites for seventeen DEW Line stations. Few knew the area well, but James Croal knew permafrost, knew the climate and worked alongside his old friend from exercise Musk Ox, Tom Manning, who had mapped the area during the war. ${ }^{36}$

Croal returned to Labrador for the 1955 cruise, which was tasked with leading a large convoy of American ships that would be delivering materials to construct the same sites Croal had helped survey that spring. His Foundation Company work at those sites was an obvious asset, It is not surprising therefore that one of his many duties as a ship's officer included that of beach master. Other positions included assistant navigator, assistant hydrographer, and search-and-rescue officer. ${ }^{37} \mathrm{Like}$ his appointment as gunnery officer, none of these represented a responsibility equal to his rank, but on paper they probably justified his addition to the ship's complement. Robertson understood the importance of his expertise, and these various minor duties offered a way around the lack of the naval establishment's post of "arctic pilot" or ice master." But it was in this responsibility that Croal demonstrated his true value.

Croal had charge of the ship during one particular watch when the ship was in the western portion of the Foxe Basin (a poorly charted area), working through some of the heaviest ice and harshest conditions they had yet faced. He suddenly stopped the ship by reversing the engines because something simply did not look right out on the ice. With the ship safely stopped, when Robertson, who had not been on the bridge, arrived, Croal told him that there was a shoal in the ship's path. Although the echo sounder was showing ample water under the keel and to the untrained eye nothing could be seen except ice and snow,

\footnotetext{
${ }^{34}$ Letter from OCS Robertson to HMC Gunnery School, 3 December 1953. PRC, Croal O-16805.

${ }^{35}$ Letter from the Foundation Company of Canada Ltd. to CO, HMCS Labrador, 25 January 1955. PRC, Croal O-16805.

${ }_{36}$ Memo from Croal to Project Manager, Eastern DEW Line, 19 March 1955. LAC, MG 31, G 34, vol. 1, file 9 .

${ }^{37}$ Croal personal resumé. LAC, MG 31, G 34, vol. 1, file 1.
} 
Captain Robertson trusted Croal's instincts. While the ship lay beset in the ice, an investigation of the area revealed an uncharted shoal of considerable size with only twelve feet of water for the icebreaker's twenty-nine feet of draught. ${ }^{38}$ Labrador's navigator, Lieutenant Commander J. H. MacLean was beside himself with disbelief as he recounted that he had transited the exact same area the previous summer as an observer in an American icebreaker, which apparently missed going hard aground on the shoal out of sheer luck. For his discovery, the navigational hazard, which lies southeast of Cape Wilson near the Arctic Circle, was named Croal Shoal. ${ }^{39}$

The incident with the shoal reinforced the confidence Captain Robertson had in Croal's abilities. With no extra staff embarked, Robertson assigned Croal as the liaison officer and de facto mission staff officer to coordinate with the Foundation Company as well as the US Navy. For their efforts that summer, both Robertson and Croal earned personal Letters of Commendation from the US secretary of the navy.

In March 1956, Croal was seconded to the Arctic Section of the Defence Research Board. ${ }^{40}$ From here, Croal co-ordinated Labrador's scientific programme for the 1956 summer cruise. Within a few short months, he was back in the eastern Arctic to assist American forces resupplying the DEW Line. ${ }^{41}$ He was also assigned the task of co-ordinating DRB's participation in the International Geophysical Year in 1957-1958; this involved a scientific expedition to establish a base camp near Hazen Lake on Northern Ellesmere Island. In order to facilitate this, Croal went onboard the US Coast Guard icebreaker Eastwind to Chandler Fiord in 1957 to coordinate logistics. ${ }^{42}$ When the scientists were finished collecting their data, the personnel and equipment needed to be extracted. The US Navy icebreaker, USS Atka, was assigned to assist in the evacuation, but the fiord was uncharted and the ice almost impenetrable. The mission was in jeopardy because the American captain was hesitant to go further into the fiord and put the ship at risk. Eventually he did and the scientific party was safely extracted with all their equipment. In a letter to the chief of the naval staff, Vice Admiral Harry DeWolf, the DRB chairman, Dr Adam Hartley Zimmerman, attributed the success of the evacuation to Big Jim's presence on the ship and his ability to convince the captain that it was safe to push through into the fiord. ${ }^{43}$ Atka was, essentially, the same design as Labrador and Croal had been through similar tough spots countless times before.

By 1958, interest in the Arctic had grown immeasurably because of American and Soviet developments in submarine technology. The Soviet Navy had launched their first nuclear submarine in August of the previous year and it was due to commission that summer. In April, the new director of naval plans and operations, Captain J.A. Charles, advised the naval staff that there was an increasing urgency to complete a full survey of the Canadian Arctic

\footnotetext{
38 Private writings. LAC, MG 31, G 34, vol. 5, file 97.

39 Sailing Directions, Arctic Canada, II, $4^{\text {th }}$ ed., 1985, 4.

${ }^{40}$ Memo from the Chief of the Naval Staff (CNS) to Chairman DRB, 27 June 1955. PRC, Croal O-16805;

The Arctic Section of DRB was renamed the Geophysics Section in 1955. Carroll, 914.

${ }^{41}$ Letter of Appreciation from CO, 7278 TTC (NEAC), 27 June 1956. PRC, Croal O-16805.

${ }^{42}$ Croal biographical sketch; Letter from Chairman, DRB to CNS, 6 October 1958. LAC, MG 31, G 34, vol.

1 , file 2 .

${ }^{43}$ Letter from Chairman, DRB to CNS, 6 October 1958. LAC, MG 31, G 34, vol. 1, file 2.
} 
and northern approaches. ${ }^{44}$ The prospect of the northern fleet operating under the ice had become a reality. Later that summer, USS Nautilus (SSN 571) made history by becoming the first vessel under its own power to reach the North Pole while a second submarine, USS Skate (SSN 578), became the first to surface through the ice at the pole. With these accomplishments and the development of submarine-launched missiles, the Arctic was becoming a Cold War theatre of naval operations

This was something that Croal had seen coming for a long time. His DRB supervisor, Frank Davies, accredited Croal with the foretelling of nuclear submarines operating under the ice close to our coasts long before Nautilus made its historic journey to the pole. After Croal had left the DRB, Davies wrote to him that his "foresight in this respect is to be commended." ${ }^{.45}$ In October 1958 Croal had been posted to the Directorate of Naval Intelligence as the foreign liaison officer. ${ }^{46}$ In this capacity he continued to work closely with the Americans on Arctic matters and nuclear submarine transits.

The autumn of 1958 was a critical time for the navy. In addition to the events mentioned above, the Naval Staff was entertaining the idea of building nuclear submarines in Canada and a special team of technical officers began their investigations into acquiring a state-ofthe-art American design. As Croal was going to naval intelligence, Captain Robertson, was promoted to commodore and sent to Washington as the senior naval member of the defence liaison staff at the Canadian embassy. Together, Croal and Robertson had forged friendships with many notable Americans within the scientific and defence establishment. None of these relationships were more influential than the one with Dr Waldo Lyon, the head of US efforts to develop under-ice capabilities for their nuclear submarine programme. One of the lesser known and highly sensitive objectives of Labrador's maiden voyage had been to pass along depth soundings taken in the Northwest Passage to Dr Lyon who, at the time, was trying to determine if a submarine could make a submerged transit. ${ }^{47}$ Lyon again asked for Robertson's assistance during the ground breaking transit. ${ }^{48} \mathrm{Croal}$, in the meantime, went back to the Arctic in May 1959 at the request of DRB to help the Pacific Naval Laboratory (PACNAVLAB) conduct a study of under-ice sound propagation southwest of Resolute Bay in Lancaster Sound - the main route through the archipelago. ${ }^{49}$ The primary purpose of this experiment was to determine the potential effectiveness of acoustic submarine detection systems under Arctic conditions in the area. ${ }^{50}$ The ease with which the research team was able to set up and conduct their experiment was attributed to Big Jim being there with his local guide, who scouted the best location to deploy the acoustic gear and establish a base camp prior to the scientific team's arrival. ${ }^{51}$

\footnotetext{
${ }^{44}$ Naval Staff meeting 4/58-2, 8 April 1958. Directorate of History and Heritage (DHH), 81/520/1000-100/3, box 38A, file 1; DHH, 79/246, box 20, file 219 .

${ }^{45}$ Letter from Frank Davies to J.P. Croal, 6 October 1958. LAC, MG 31, G 34, vol. 1, file 2.

${ }^{46}$ Letter from CNS to Chairman, DRB, 22 September 1958. PRC, Croal O-16805.

${ }^{47}$ Lieutenant(N) Jason M. Delaney and Michael Whitby, " 'The very Image of a Man of the Arctic':

Commodore O.C.S. Robertson," Canadian Naval Review, (Winter 2009): 27.

${ }^{48}$ Ibid, p. 25-29.

${ }^{49}$ Lieutenant Commander J.P. Croal, Report on Operation Paclabar, 10 April to 1 May 1959. LAC, MG 31, G 34, vol. 6, file 128 .

${ }^{50}$ Memo from Chairman, DRB to CNS, 2 September 1960. DHH, 79/246. folder 46.

${ }^{51}$ Letter from Chairman, DRB to CNS, no date on copy but otherwise identified as 15 June 1959. LAC, MG 31, G 34, vol. 1, file 2 .
} 
Unfortunately, in 1961 Croal reached compulsory retirement age for his rank and was honourably released from service. ${ }^{52}$ He was immediately picked up by Spartan Air Service - an aerial mapping and geophysical survey company involved in completing surveys of the Canadian archipelago. At Naval Service Headquarters, an ad hoc committee was set up to determine a comprehensive vision for the navy and the future of the fleet. ${ }^{53}$ Among other things, it included the requirement for naval forces to be able to operate in the Arctic, including the need for forward basing, because the submarine threat in the Arctic had become a legitimate concern and a national defence priority.

A few months before the release of the navy's report, the nuclear submarine, USS Seadragon (SSN 584), made the planned submerged transit of the Northwest Passage and continued on to surface at the North Pole with both Dr Lyon and Commodore Robertson onboard. With this accomplished, one of Dr Lyon's major goals was finally realized and a new era of submarine operations was inaugurated. All of this did not go unnoticed as the minister of Northern Affairs and National Resources, Walter Dinsdale, wrote to the defence minister, Douglas Harkness with alarm, "you know far better than I that developments in both missiles and nuclear powered submarines are giving a new strategic significance to northern Canada. This cannot fail to result in naval activity in and around Hudson Bay and the Canadian Arctic archipelago. This summer in fact, two US naval submarines have been operating in these waters." 54

When the navy's future fleet requirements were released, Croal was asked to return to temporary active duty as the staff officer (Arctic requirements). He reported to the director of naval operational requirements, Captain P.F.X. Russell, who needed articulate the navy's requirements in the north; thus, in May 1962, Croal helped draft the "Staff Study for the Operational Requirements in the Canadian Arctic." 55

By March 1963, the naval policy co-ordinating committee accepted the study as a basic planning document and agreed to the three phase plan to develop countermeasures to the threat from the polar region. ${ }^{56}$ The objective was to assess the growing threat of enemy submarines operating in the Canadian Arctic so that a defence could be planned. The study, however, was not a solution - it simply set out the problem and identified what needed to be done. First and foremost, the hydrographic survey of the Arctic had to be completed. Croal was tasked with co-ordinating the survey work for the report that would follow. ${ }^{57}$ Additionally, Croal helped PACNAVLAB with another experiment called SEA MAG II aimed at determining if submarines operating under the ice were susceptible to magnetic

\footnotetext{
52 Letter from Naval Secretary to CO, HMCS Bytown, 29 November 1960. LAC, MG 31, G 34, vol. 1, file 2.

${ }^{53}$ Report of the Ad Hoc Committee on Naval Objectives (Brock Report), July 1961. DHH, 99/31, box 5, file II-1.

${ }^{54}$ Letter from Dinsdale to Harkness, 9 November 1960. Naval Policy Co-ordinating Committee (NPCC) File J-7. DHH, 79/246, folder 46.

${ }_{55}$ Staff Study of Operational Requirements for the Canadian Arctic, 19 February 1963. NPCC project file NN-2. DHH, 79/246, folder 9.

${ }^{56}$ NPCC project file NN-2, "Research - RCN Arctic Tasks," DHH, 79/246, file 207.

${ }^{57}$ Croal personal résumé.
} 
detection. ${ }^{58}$ These experiments represented the first attempts at a defence against the nuclear submarine threat in the Arctic.

Things seemed to be well in hand, but having worked with the scientific community, Croal knew that Canadian and allied knowledge in the Arctic was about twenty years behind that of the Soviets..$^{59}$ Although there was considerable charting, photo reconnaissance and surveying during this period, the information was incomplete especially in places that were difficult to reach by survey ship. This was certainly the case for the area between northern Devon Island and the southwest tip of Ellesmere Island where a passage south could be accomplished either through Hell Gate or Cardigan Strait. ${ }^{60}$

Based on his experience with Spartan Air Service, Croal knew of an alternate method. ${ }^{61}$ Spartan used special mapping equipment slung below helicopters in order to map vast areas in a short period of time. Croal knew this method had great potential when used with echo sounders because helicopters could get to remote locations where survey ships could not. This was especially relevant in ice-chocked areas of the high Arctic. In fact, the technique was being used with considerable success by the Polar Continental Shelf Project as early as 1961. The RCN was providing funding to the project in order to complete the Arctic defence survey. Thus, the naval hydrographer, on old shipmate of Croal's, Lieutenant Commander Tom Irvine ${ }^{62}$ was receiving all the necessary information collected by the project to complete the plan laid out in Croal and Russell's staff study ${ }^{63}$ Subsequently, Croal was appointed as a member of the Arctic Defence Working Group and together with Irvine, prepared an analysis of the potential transit routes and operational areas for submarines in the Canadian Arctic. ${ }^{64}$

The use of helicopters allowed the project to obtain hydrographic information significantly faster than would have been the case with ships. The influx of information collected facilitated negotiations with the US to access valuable underwater data obtained by US nuclear submarines in order to complete the survey - information Canada would not have otherwise been given ${ }^{65}$ Because of this, Canada and the United States exchanged a vast amount of information in 1964. For his part in these and other efforts, Croal's director nominated him for the Royal Canadian Geographical Society's Massey Medal in 1964 writing, "It is thus not surprising that he has become the Arctic expert of the Royal Canadian Navy and further that his advice on Arctic matters is also constantly sought by other

\footnotetext{
${ }^{58}$ Letter of Appreciation from the Chief Superintendent PACNAVLAB, 30 May 1963. PRC, Croal O-16805. One week later, LCdr Croal gave a verbal briefing to the Naval Staff on magnatometer trials at Resolute Bay most likely in connection with these experiments. Naval Staff, 8/63, 6 June 1963. DHH, 81/520/1000-100/3, box 35 , file 2 .

${ }_{59}$ Report on Operation Hazen, 28 April to 30 May 1958. LAC, MG 31, G 34, vol. 1, file 13.

${ }^{60}$ Minute sheet of the Research Control Committee, nd. DHH, 79/246, box 20, file 219.

${ }^{61}$ Spartan had developed a method to survey vast amounts of territory, quickly using a mapping sensor carried at tree top level by helicopters. See Norman Avery, Spartan: Seven Letters that Spanned the Globe, (privately published by Norman Avery, 2009); Croal biographical sketch.

${ }_{62}$ Lieutenant Commander Tom Irvine was another experienced Arctic sailor having been Labrador's hydrographer during the icebreaker's maiden voyage and thus a former shipmate of Croal's.

${ }_{63}^{63}$ Letter from DNOR to ACNS(A\&W), 21 April 1964. NPCC project file NN-2. DHH, 79/246, file 207.

${ }^{64}$ Minutes of the First Meeting of the Arctic Defence Working Group, 4 October 1963. DHH, 79/246, folder 12.

${ }_{65}$ Minutes of the First Meeting of the Arctic Defence Working Group, 9 October 1963. DHH, 79/246, folder 12.
} 
Government Departments. " ${ }^{\prime 66}$ Unfortunately, Big Jim did not receive the award. The recipient for 1964 was Yves Fortier, a geologist who had led several expeditions into the Canadian Arctic that identified significant potential oil and gas deposits. Nonetheless, Jim Croal was part of prestigious group of Arctic specialists and had lasting friendships with no less than six of the medal's recipients including: Henry Larsen (1959), Owen Robertson (1961), Graham Rowley (1963), Moira Dunbar (1972), Tom Manning (1977) and Tom Pullen (1984). ${ }^{67}$

The RCN's Arctic Defence Working Group completed its study in 1965 entitled, "A Staff Paper on Canadian Anti-Submarine Defence in the Arctic," outlining the potential submarine transit routes through the Archipelago and recommended areas for detection devices. ${ }^{68}$ Croal quietly left the naval service in October 1965, but continued to work on Arctic matters with the Department of Indian Affairs and Northern Development, the Defence Research Board, the Department of the Environment and the Arctic Institute of North America. From 1970-71, he was hired as a consultant and served under contract with DRB as the assistant study director for the North Atlantic Treaty Organization long term study on scientific and technical aspects of military operations under Arctic conditions. ${ }^{69}$

James Croal died on 13 January 1985 at the age of 67. It was a year Canada's Arctic sovereignty gained national importance as a result of the Polar Sea incident. ${ }^{70}$ His obituary, written by Dr Hattersley-Smith, appeared in volume 22, issue 141 of the Polar Record. One of Canada's most notable northern nationalists, ${ }^{71}$ Dr Hugh Keenleyside, once referred to the North as not just a geographic area, but a way of life and a habit of mind. He believed that it was a true frontier that would never be fully conquered. ${ }^{72}$ When James Croal was instructing the Arctic survival course at Fort Churchill, he taught that to survive and travel in the Arctic, a man must have complete confidence in himself and his decisions. This confidence is built on a liking and deep respect for the country as well as knowledge of the local terrain and indigenous people. Other than this, a man needs only simple navigation skills and the ability to travel and be comfortable under all types of conditions. ${ }^{73}$

\footnotetext{
${ }^{66}$ Letter from DNOR to CNS, 14 May 1964; Letter from Chairman, DRB to CNS, 21 May 1964. PRC, Croal O-16805.

${ }^{67}$ Tom Manning as well as Moira Dunbar's brother, Maxwell, were two individuals identified in Shelagh Grant's article on Canada's northern nationalists as being important figures with respect to Canadian Arctic developments. Shelagh D. Grant, "Northern Nationalists: Visions of, "A New North," 1940-1950," For Purposes of Dominion: Essays in Honour of Morris Zaslow, ed. Kenneth Coates and William Morrison, (North York, 1989), 47-70. Croal knew Henry Larsen from his time onboard Labrador and remained friends through this tight social group long after both left their respective services. Tom Pullen was HMCS Labrador's second, and subsequently, last commanding officer.

${ }^{68}$ J.P. Croal, Urgent Needs for Operations in the North, c. 1965. LAC, MG 31, G 34, vol. 6, file 146.

${ }^{69}$ Croal personal resumé.

${ }^{70}$ The Polar Sea incident refers to the American icebreaker USCGC Polar Sea that transited the Northwest Passage without gaining permission from the Canadian government, which considers the waterway internal Canadian waters. The incident sparked a political and diplomatic controversy between Canada and the United States.

${ }^{71}$ Shelagh Grant uses the term "Northern Nationalists" in her article on the subject. Grant, "Northern Nationalists."

${ }^{72}$ Grant, "Northern Nationalists," 65.

73 J.P. Croal. Draft, Indoctrination and Training Course for Sub-Arctic Instructors, 5 April 1950. LAC, MG 31, G 34, vol. 5, file 104.
} 
His associations with legendary Arctic hands such as Patrick Baird, Graham Rowley, Andrew Croft, Tom Manning and Owen Robertson all had a significant influence on his life. He did not just know how to survive in the Arctic; he knew how to thrive in it. He loved the land, the people and the way of life. The life and times of Lieutenant Commander James Patrick Croal provide a unique window to look into a significant period of the Cold War as it pertains to the activities in the North. He deserves to be remembered for his considerable part in Arctic developments because he was present for a series of firsts. He was a part of the first post-war military expedition to venture above the Arctic Circle. He was the first DRB employee to establish what would later become the Defence Research Northern Laboratory. He was onboard HMCS Labrador for her legendary voyage through the Northwest Passage and he helped establish numerous northern outposts and stations throughout the Arctic archipelago.

Perhaps most importantly, James Croal was instrumental in completing the first strategic assessment of the Arctic identifying possible enemy submarine routes through Canadian northern waters. Over the course of his career, he helped define and defend Canada's northern frontier. For his contributions to polar research, he was elected a Fellow of the Arctic Institute of North America (1962), nominated for the Massey medal (1964) and elected, posthumously, into the Waterloo County Hall of Fame (1999).

James Croal gained the respect of many eminent scientists, military leaders and northern pioneers. He made lasting friendships and worked alongside all three military services, the coast guard and the scientific communities of both the United States and Canada. In the end, it can be said that he was the right man in the right place at the right time and the crew of HMCS Labrador would have certainly agreed after their close call with Croal Shoal in the summer of 1955 on Canada's northern frontier. 